\section{Oral Cleansing with Chlorhexidine to Decrease the Incidence of Nosocomial Pneumonia: Using the Right Concentration in the Right Place}

To the Editor-We read with interest the recent study Bellissimo-Rodrigues et $\mathrm{al}^{1}$ on the use of $0.12 \%$ chlorhexidine for prevention of nosocomial pneumonia. The authors concluded that $0.12 \%$ chlorhexidine was not effective in decreasing the incidence of nosocomial respiratory infection. However, chlorhexidine prolonged the infection-free survival time in this study. We have a few observations.

In the present study, $0.12 \%$ chlorhexidine prolonged the onset of lower respiratory tract infections (11.3 days, compared with 7.6 days for placebo). However, the organisms isolated from these patients were not reported. Chlorhexidine is a broad-spectrum antiseptic with significant activity against gram-positive bacteria. ${ }^{2}$ Therefore, it is necessary to investigate whether this delay in the onset of first respiratory infection was also accompanied by a difference in the microbial etiologies.

In a larger, single-center study, we recently found that oropharyngeal cleansing with $0.2 \%$ chlorhexidine did not decrease the incidence of nosocomial pneumonia among intensive care unit (ICU) patients, although length of ICU stay was reduced in intubated patients and those receiving mechanical ventilation. ${ }^{3}$ Similarly, other studies using chlorhexidine in a concentration of $0.2 \%$ or less in ICU patients reported improvement in surrogate outcomes but not in the incidence of pneumonia or mortality. ${ }^{4-6}$ In contrast, the 2 studies of $2 \%$ chlorhexidine for oropharyngeal cleansing both showed reduction in the incidence of pneumonia. ${ }^{7,8}$ Therefore, we suggest that future studies of oral cleansing with chlorhexidine among ICU patients should use higher concentrations $(2 \%)$.

\section{ACKNOWLEDGMENTS}

Potential conflicts of interest. All authors report no conflicts of interest relevant to this article.

\section{Tanmay S. Panchabhai, MD; Neha S. Dangayach, MD}

From the Department of Medicine, University of Louisville School of Medicine, Louisville, Kentucky (T.S.P.); and Department of Neurology, University Hospitals of Case Medical Center, Case Western Reserve University, Cleveland, Ohio (N.S.D.).

Address reprint requests to Tanmay S Panchabhai, MD, ACB, Third Fl, 550 S Jackson St, Department of Medicine, University of Louisville School of Medicine, Louisville, KY 40202 (tspanchabhai@hotmail.com).
Infect Control Hosp Epidemiol 2010; 31:429

(C) 2010 by The Society for Healthcare Epidemiology of America. All rights reserved. 0899-823X/2010/3104-0021\$15.00. DOI: $10.1086 / 651307$

\section{REFERENCES}

1. Bellissimo-Rodrigues F, Bellissimo-Rodrigues WT, Viana JM, et al. Effectiveness of oral rinse with chlorhexidine in preventing nosocomial respiratory tract infections amongst intensive care unit patients. Infect Control Hosp Epidemiol 2009; 30:952-958.

2. Ascenzi JM, Favero MS. Disinfectants and antiseptics, modes of action, mechanisms of resistance, and testing. In: Lorian V, ed. Antibiotics in laboratory medicine. 5th ed. Philadelphia: Lippincott Williams and Wilkins, 2005:615-653.

3. Panchabhai TS, Dangayach NS, Krishnan A, Kothari VM, Karnad DR. Oropharyngeal cleansing with $0.2 \%$ chlorhexidine for prevention of nosocomial pneumonia in critically ill patients: an open label randomized trial with $0.01 \%$ potassium permanganate as control. Chest 2009; 135 : 1150-1156.

4. Fourrier F, Cau-Pottier E, Boutigny $\mathrm{H}$, et al. Effects of dental plaque antiseptic decontamination on bacterial colonization and nosocomial infections in critically ill patients. Intensive Care Med 2000; 26:1239-1247.

5. Fourrier F, Dubois D, Pronnier $P$, et al. Effect of gingival and dental plaque antiseptic decontamination on nosocomial infections acquired in the intensive care unit: a double-blind placebo-controlled multicenter study. Crit Care Med 2005; 33:1728-1735.

6. MacNaughton P, Bailey J, Donlin N, et al. A randomized controlled trial assessing efficacy of oral chlorhexidine in ventilated patients. European Society of Intensive Care Medicine, 17th Annual Congress, Berlin, Germany. Intensive Care Med 2004; 30(Suppl 1):S5-S18.

7. Koeman $M$, van der Ven AJ, Hak E, et al. Oral decontamination with chlorhexidine reduces incidence of ventilator-associated pneumonia. Am J Respir Crit Care Med 2006; 173:1348-1355.

8. Tantipong H, Morkchareonpong C, Jaiyindee S, et al. Randomized controlled trial and meta-analysis of oral decontamination with $2 \%$ chlorhexidine solution for the prevention of ventilator-associated pneumonia. Infect Control Hosp Epidemiol 2008; 29:131-136.

\section{Reply to Panchabhai and Dangayach}

To the Editor-We appreciate the comments by Panchabhai and Dangayach ${ }^{1}$ regarding our article ${ }^{2}$ analyzing the effectiveness of $0.12 \%$ chlorhexidine as an oral rinse for prevetion of respiratory tract infections among intensive care unit patients.

Panchabhai and Dangayach ${ }^{2}$ ask us about the microorganisms isolated from the patients during study, wondering whether any differences could be detected between experimental and control patients. We were able to identify the etiologic agent of infection in almost one-half of the episodes diagnosed (22 of 46). Among those microorganisms, 4 were gram-positive cocci ( 2 in each arm of the study; $P>.99$ ), and 18 were gram-negative bacilli ( 9 in each arm of the study; 